43. The relationship between sarcopenia and fragility fracture - a systematic review / R.M.Y. Wong et al. Osteoporos. Int. 2019. Vol. 30, No. 3. P. 541-553. DOI: https://doi.org/10.1007/s00198-018-04828-0

44. Wilson D., Jackson T., Sapey E., Lord J. M. Frailty and sarcopenia: The potential role of an aged immune system. Ageing Res. Rev. 2017. Vol. 36. P. 1-10. DOI: https://doi.org/10.1016/j.arr.2017.01.006
45. Yu R., Leung J., Woo J. Incremental predictive value of sarcopenia for incident fracture in an elderly chinese cohort: Results from the osteoporotic fractures in men (MrOs) study. J. Am. Med. Dir. Assoc. 2014. Vol. 15, No. 8. P. 551-558.

DOI: https://doi.org/10.1016/j.jamda.2014.02.005
The article was received 2020.09.04
O.R. Vintoniv *,
I.R. Popadynets,
V.I. Hrodzinskyy ",
S.V. Melnyk*,
P.R. Herych,
I.M. Halipchak*

\title{
ALGORITHM OF DIAGNOSTICS OF ERECTILE DYSFUNCTION IN PATIENTS WITH ARTERIAL HYPERTENSION AND DYNAMICS OF ARTERIAL BLOOD PRESSURE AGAINST THE BACKGROUND OF ANDROGENIC DEFICIENCY
}

Ivano-Frankivsk National Medical University

Department of Internal Medicine N 1

Halytska str., 2, Ivano-Frankivsk, 76000, Ukraine

e-mail: nvchernjuk@gmail.com

Regional Clinical Hospital Municipal Non-Commercial Enterprise of Ivano-Frankivsk Regional Council ${ }^{*}$

Fedkovycha str., 91, Ivano-Frankivsk, 76000, Ukraine

e-mail:hospital.if.ua@gmail.com

Івано-Франкіський національний медичний університет

кафедра внутрішньої медицини № 1

(зав. - д. мед. н., проф. Н.В. Чернюк)

вул. Галицька, 2, Івано-Франківськ, 76000, Україна

КНП Обласна клінічна лікарня (ОКЛ) Івано-Франківської обласної ради *

(головн. лікар - к. мед. н. О.І. Грищук)

вул. Федьковича, 91, Івано-Франківськ, 76000, Україна

\footnotetext{
Цитування: Медичні перспективи. 2021. Т. 26, № 2. С. 119-125

Cited: Medicni perspektivi. 2021;26(2):119-125
}

Key words: erectile dysfunction, color Doppler imaging, androgen deficiency, arterial hypertension Ключові слова: еректильна дисфункиія, кольорова доплерографія, андрогенний дефіцит, артеріальна гіпертензія

Ключевые слова: эректильная дисфункция, ияветная допплерография, андрогенный дефицит, артериальная гипертензия

Abstract. Algorithm of diagnostics of erectile dysfunction in patients with arterial hypertension and dynamics of arterial blood pressure against the background of androgenic deficiency. Vintoniv O.R., Popadynets I.R., Hrodzinskyy V.I., Melnyk S.V., Herych P.R., Halipchak I.M. In recent years, the requirements for the level of the 
life quality have increased significantly; an integral part of it is the sexual harmony, which in men largely depends on sexual desire and erectile function. According to the results of modern scientific studies, there is no doubt that erectile dysfunction in men is closely connected with the cardiovascular diseases, obesity, diabetes mellitus and other comorbidities. This problem can also be caused by systematic psycho-emotional overload, deterioration of the environmental conditions, harmful factors of production, uncontrolled use of medicines, inflammatory processes in the genital organs, the growth of somatic diseases. The vast majority of works concerning "male menopause" is reduced to the effectiveness of hormone-replacement therapy in erectile dysfunction, while only few research works are devoted to the study of the connection between somatic pathology and androgen deficiency. There is a negative correlation between total testosterone level and systolic blood pressure. According to the research results of some scientists, it was found that $38 \%$ of patients with arterial hypertension had androgen deficiency, confirmed in the laboratory, which is significantly higher than in patients of the same age category with normal blood pressure. These dominant factors exert and increase the influence on each other, which must be taken into account in modern therapeutic practice. The study of the formation of comorbid conditions in men with low levels of androgens is of particular importance, as the knowledge of pathophysiological mechanisms can prevent their development and progression. The aim of this investigation was to study the state of penile vascular blood flow in men with arterial hypertension with erectile dysfunction, using color Doppler imaging with pharmacological induction of erection. The indicators of daily monitoring of arterial pressure and arterial stiffness in men with arterial hypertension of the II degree against the background of androgen deficiency or at normal testosterone levels and ways of correction of erectile dysfunction in these patients were also evaluated.

Реферат. Алгоритм діагностики еректильної дисфункції в паціснтів 3 артеріальною гіпертензісю та динаміка артеріального тиску на фоні андрогенного дефіциту. Вінтонів О.Р., Попадинець І.Р., Гродзінський В.I., Мельник С.В., Герич П.Р., Галіпчак І.М. В останні роки значно зросли вимоги до рівня якості життя, невід'ємною частиною якого є сексуальна гармонія, яка в чоловіків значною мірою залежить від статевого потягу й еректильної функиії. Згідно з результатами сучасних наукових досліджень, не виникає сумнівів, щчо еректильна дисфункція в чоловіків тісно пов'язана з серцево-судинними захворюваннями, ожирінням, иукровим діабетом та іншими супутніми патологіями. Ця проблема також може бути зумовлена систематичними психоемоційними перевантаженнями, погіршенням екологічних умов, шкідливими чинниками виробництва, безконтрольним використанням медичних препаратів, запальними процесами статевих органів, зростанням соматичних захворювань. Переважна більшість робіт стосовно «чоловічого клімаксу» зводиться до ефективності замісної гормональної терапії при еректильній дисфункиї, тоді як вивченню зв'язку соматичної патології з андрогенною недостатністю присвячені поодинокі дослідження. Відзначається негативний кореляційний зв'язок між рівнем загального тестостерону та систолічним артеріальним тиском. Згідно з результатами досліджень деяких вчених, виявлено, щчо 38\% пацієнтів з артеріальною гіпертензією мали дефіцит андрогенів, який підтверджувався лабораторно, щэо достовірно вище, ніж у пацієнтів тієї ж вікової категорії з нормальним рівнем артеріального тиску. Ці домінувальні чинники здійснюють та посилюють вплив один на одного, щчо обов'язково необхідно враховувати в сучасній терапевтичній практиці. Особливого значення набуває вивчення формування коморбідних станів у чоловіків зі зниженим рівнем андрогенів, оскільки знання патофізіологічних механізмів може запобігти їх розвитку і прогресуванню. Метою цьього дослідження було вивчення стану пенільного судинного кровотоку в чоловіків, хворих на артеріальну гіпертензію з еректильною дисфункиією, иляхом кольорової доплерографії з фармакологічною індукцією ерекиї. Також оцінювалися показники добового моніторингу артеріального тиску та жорсткості артерій у чоловіків з артеріальною гіпертензією II ступеня на фоні андрогенного дефіциту або при нормальному рівні тестостерону та иляхи корекції еректильної дисфункиії в цฺих пацฺієнтів.

According to the World Health Organization estimates, there is approximately $40 \%$ of people worldwide who have high blood pressure (BP). Arterial hypertension $(\mathrm{AH})$ is one of the leading causes of mortality worldwide and increases the risk of overall mortality by 4.5 times in men and by 2.0 in women. High blood pressure significantly increases the risk of coronary heart disease, stroke, as well as heart and kidney failure, leads to the vascular and eye damage $[6,15]$. The presence of AH not only increases the risk of overall mortality, but also significantly affects life expectancy, reducing it by 9 years in men and by 7 - in women. Male gender is considered as an independent risk factor for hypertension. According to the
EUROASPIRE IV study, the prevalence of AH among men is consistently higher compared to the female population $[5,6,11]$.

Cardiovascular diseases and sexual health have the same common risk factors $(\mathrm{AH}$, diabetes mellitus, dyslipidemia, obesity and smoking) and common mechanisms of pathological changes development (endothelial dysfunction, subclinical inflammation and atherosclerosis) $[3,16]$.

Androgen deficiency is considered as an important factor in the occurrence and progression of cardiovascular disease $[1,17]$. The prevalence of testosterone deficiency among men older than 45 years is $12-38.7 \%$, and among patients with hypertension $-42.4 \%$. Testosterone deficiency is 
considered to be a predictor of future cardiovascular events in men with $\mathrm{AH}$, and the development of symptoms of erectile dysfunction (ED) may precede the onset of cardiovascular pathology 2-3 years before its manifestations, that has the social importance [4].

There is more and more evidence that ED may be an early manifestation of coronary and peripheral vascular disease. The development of ED is facilitated by the same factors that activate atherosclerosis, namely: arterial hypertension, dyslipidemia, diabetes mellitus, smoking [12].

Currently, the prevalence of ED among men of different age is estimated as $10 \%$, and in the group of men aged 40-70 years, it reaches 52\% [7]. Approximately 150 million people worldwide suffer from this progressive disease. According to the WHO, every tenth man over the age of 21 suffers from erectile dysfunction, and every third man over the age of 60 is not able to perform sexual intercourse at all [2].

ED can affect both physical and psychosocial health, significantly impairs the quality of life (QL) of patients and their partners; thus, it should be considered not only as a QL problem, but also as a potential warning sign of cardiovascular disease [8].

The available data indicate a negative effect of low testosterone level on the development and progression of cardiovascular diseases in men [15]. Therefore, this problem is extremely relevant and requires a thoughtful medical approach.

According to the Order of the Ministry of Health of Ukraine №330 dated 15.06.2007, the diagnostic program of ED includes: 1) interrogation and survey using IIEF questionnaires (International Index of Erectile Function); 2) examination; 3) laboratory tests: blood glucose level; lipid profile; level of testosterone, prolactin, estradiol, follicle-stimulating and luteinizing hormones; 4) test with local negative pressure (LNP); 5) rheophallography at rest; 6) dopplerography of cavernous vessels at rest and after pharmacological loading (intracavernous administration of $2 \mathrm{ml}$ of Papaverine Hydrochloride) [8].

Of all causes of sexual disorders, vascular ED makes up $70 \%$. After excluding the endocrine and psychogenic nature of the disease, based on conventional tests, in order to diagnose arterial ED, a test with Sildenafil and visual erectile stimulation during ultrasound of penile blood flow is performed [13].

The objective of the study - to investigate the state of penile vascular blood flow in men with $\mathrm{AH}$ with sexual disorder using color Doppler imaging with pharmacological induction of erection, evaluation of daily blood pressure parameters and artery stiffness in men with AH of the II degree, and lipid profile against the background of androgen deficiency or normal testosterone level and ways to correct ED in these patients.

\section{MATERIALS AND METHODS OF RESEARCH}

We have performed color Doppler imaging of the vessels of the penis with pharmacological induction of erection in men with sexual disorders against the background of arterial hypertension. Patients whose total score, according to the questionnaire, corresponded to the presence of symptoms of testosterone decline, were included into the study for further determination of total testosterone (TT). All persons studied were performed daily blood pressure monitoring (DMBP) [15] and assessment of arterial stiffness using the BPLab Vasotens system (using oscillometric method) [13].

Research methods: general clinical, anamnestic, biochemical, special sexological, ultrasound, sociological and statistical. Bibliosemantic, analyticalsynthetic, comparative analyses were also used in the work.

There were examined 110 patients. Age of patients was 35-66 years, body weight averaged $76.9 \pm 5.4 \mathrm{~kg}$; body mass index $-25.7 \pm 2.2 \mathrm{~kg} / \mathrm{m}^{2}$. The control group consisted of 20 healthy men.

The concentration of total, bioavailable testosterone was determined using enzyme-linked immunosorbent assay (Hema system, Spain).

Studying the state of lipid metabolism, the level of total cholesterol, triglycerides, HDL cholesterol and b-lipoproteins in the blood serum were determined using reagents "Human" (Germany) on the Stat Fax analyzer. The coefficient of atherogenicity was determined according to the formula of A.M. Klimov: coefficient of atherogenicity $=$ (total cholesterol - HDL cholesterol)/HDL cholesterol [9]. All the results obtained were compared with the corresponding age norms of these indicators.

Doppler imaging was performed in the longitudinal and transverse planes at the level of the proximal, middle third of the penis. Doppler imaging of the penis made it possible to visualize the deep artery of penis in longitudinal section, to visualize the superficial and deep dorsal veins on the surface of the penis in the form of a tubular structure that easily changes in diameter when compressed by a sensor, to obtain the Doppler spectrum of blood flow from the cavernous arteries at rest and during pharmacological erection induction [13].

The study determined the main Doppler parameters - peak (maximal) systolic velocity (PSV), end (terminal) diastolic velocity (EDV) and resistance index (RI).

The first stage was performed without erectile stimulation and was defined as basic one. Baseline 
maximum systolic velocity less than $25 \mathrm{~cm} / \mathrm{s}$ was considered as reduced (in the phase of swelling). After the first stage, it was the second one - scanning after intracavernous administration of papaverine hydrochloride at a dose of $2.5 \mathrm{ml}$.

The statistical processing of the obtained data was carried out using the statistical analysis package Statistica 6.0. (License - FreeBSD). Changes in parameters were considered to be reliable at $\mathrm{p}<0.05$. Significance of differences of mean values was determined using the Student criterion [14].

\section{RESULTS AND DISCUSSION}

We have noted a negative correlation between TT concentration and systolic blood pressure (SBP). There were $43 \%(n=42)$ of patients who had biochemically confirmed low testosterone level. The overall MASSQ score in this group was significantly higher compared to those with normal testosterone level. There was a decrease in the concentration of TT with age. The group of patients with low TT levels was characterized by significantly higher values of SBP and pulse blood pressure (PBP) according to DMBP. The daily blood pressure profile in the androgen deficiency group was characterized by a predominance of "non-dipper" $[4,11]$. Multiple regression results showed an association between testosterone level and SBP values in both groups, while the correlation between testosterone and diastolic blood pressure values was not statistically significant. The correlation between TT and pulse wave velocity was strong in each group.

According to the results of the study, hypertriglyceridemia was detected in people with blood pressure: the level of triglycerides was $1.93 \pm 0.07 \mathrm{mmol} / 1$ and $1.25 \pm 0.06 \mathrm{mmol} / \mathrm{l}$ in the control group. Indicators of $\beta$-lipoproteins in patients with $\mathrm{AH}$ were $3.85 \pm 0.64 \mathrm{mmol} / \mathrm{l}$. In the control group, these values were $2.06 \pm 0.47 \mathrm{mmol} / \mathrm{l}$. The atherogenic coefficient was significantly higher in men with arterial hypertension against the indices of control group $3.04 \pm 0.86 \mathrm{mmol} / 1$ and $1.83 \pm 0.62$, respectively.

Therefore, according to the results of this study, it was found that lipid metabolism is the basis for the occurrence of atherosclerosis, obliterating endarteritis and arterial hypertension.

The study revealed a decrease in TT in patients with $\mathrm{AH}-10.40 \pm 3.49 \mathrm{nmol} / \mathrm{l}$, while in the control group these values were $16.88 \pm 4.01 \mathrm{nmol} / 1$ of the same age category.

Taking into account the results of our study, the influence of atherosclerotic lesions of the intima of blood vessels on testosterone secretion by Leydig's cells cannot be excluded.

When performing color Doppler imaging, as a norm we have taken the indices: PSV $25 \mathrm{~cm} / \mathrm{s}$ and more, EDV up to $5 \mathrm{~cm} / \mathrm{s}$ and less, RI 0.85 and more.

Baseline PSV values in almost healthy men were in the range of $43 \pm 0.90 \mathrm{~cm} / \mathrm{s}$. Basic examination of patients with ED against the background of $\mathrm{AH}$, has revealed normal PSV in only 9 patients out of 100 examined. Further pharmacological induction of erection in these patients was not performed.

In 72 patients $P S V$ index was lower than $25 \mathrm{~cm} / \mathrm{s}$ (Table 1): $20-24 \mathrm{~cm} / \mathrm{s}$ in 21 patients, $15-19 \mathrm{~cm} / \mathrm{s}$ in 24 patients, $10-15 \mathrm{~cm} / \mathrm{s}$ in 20 patients and less than $10 \mathrm{~cm} / \mathrm{s}$ in 7 patients.

Table 1

\section{Characteristics of the main Doppler indices before pharmacologic stimulation $(M \pm m)$}

\begin{tabular}{l|c|c}
\hline Indices of color Doppler imaging & $\begin{array}{c}\text { Control group } \\
(\mathrm{n}=20)\end{array}$ & $\begin{array}{c}\text { Arterial component } \\
(\mathrm{n}=72)\end{array}$ \\
\hline PSV (peak systolic velocity), cm/s & $43 \pm 0.90$ & $15.5 \pm 0.26 *$ \\
PDV (peak diastolic velocity), cm/s & $4.8 \pm 2.82$ & $4.2 \pm 0.26^{*}$ \\
RI (resistance index) & $0.88 \pm 1.38$ & $0.72 \pm 3.29 *$ \\
\hline
\end{tabular}

Note: * significance of difference between the parameters compared to the $\mathrm{CG}(\mathrm{p}<0.05)$

Pharmacological induction of erection with papaverine hydrochloride at a dose of $2.5 \mathrm{ml}$ in the group of almost healthy men was performed in only five patients (Table 2). They had a full erection during the $10^{\text {th }}-15^{\text {th }}$ minute after stimulation with high blood flow and complete dilation of the cavernous arteries on both sides.
Among 25 patients who did not have an erection after its induction, 19 patients had severe venous insufficiency, PDV was more than $5 \mathrm{~cm} / \mathrm{s}$. This was considered as mixed vascular ED. In 6 other cases there was not observed venous insufficiency, but there was significant cavernous fibrosis and damage of the arteries. In 63 men, after the induction of 
erection, a full erection was obtained, but only after 20 minutes (Table 2). Normal values of RI (more than 0.85 ) and PDV less than $5 \mathrm{~cm} / \mathrm{s}$ after the medicine administration indicate an arterial type of ED.

A study of the arterial system in papaverineinduced erection using color Doppler imaging showed that in men without arterial hypertension, the peak systolic blood flow rate was $27-59 \mathrm{~cm} / \mathrm{s}$ for the right and left cavernous arteries, respectively. In sexually active men with concomitant $\mathrm{AH}$, the peak systolic blood flow rate was $24-47 \mathrm{~cm} / \mathrm{s}$ for the right and left cavernous arteries, respectively.

\section{Characteristics of the main Doppler indices after pharmacologic stimulation with $2.5 \mathrm{ml}$ of papaverine hydrochloride during the $15^{\text {th }} \mathrm{min}(\mathrm{M} \pm \mathrm{m})$}

\begin{tabular}{l|c|c|c}
\hline Indices of color Doppler imaging & $\begin{array}{c}\text { Control group } \\
(\mathrm{n}=5)\end{array}$ & $\begin{array}{c}\text { Arterial component } \\
(\mathrm{n}=72)\end{array}$ & $\begin{array}{c}\text { Venous Component } \\
(\mathrm{n}=19)\end{array}$ \\
\hline PSV (peak systolic velocity), cm/s & $43 \pm 0.90$ & $24.5 \pm 0.54^{*}$ & $20.1 \pm 0.54$ \\
PDV (peak diastolic velocity), cm/s & $4.8 \pm 2.82$ & $3.2 \pm 0.32^{*}$ & $6.5 \pm 1.38$ \\
RI (resistance index) & $0.88 \pm 1.38$ & $0.86 \pm 2.87^{*}$ & $0.67 \pm 2.86$ \\
\hline
\end{tabular}

Note: * significance of difference between the parameters compared to the $\mathrm{CG}(\mathrm{p}<0.05)$

According to the results of the study, a direct correlation was found between PSV and TT levels in men with arterial hypertension and in patients of the control group (Fig.).

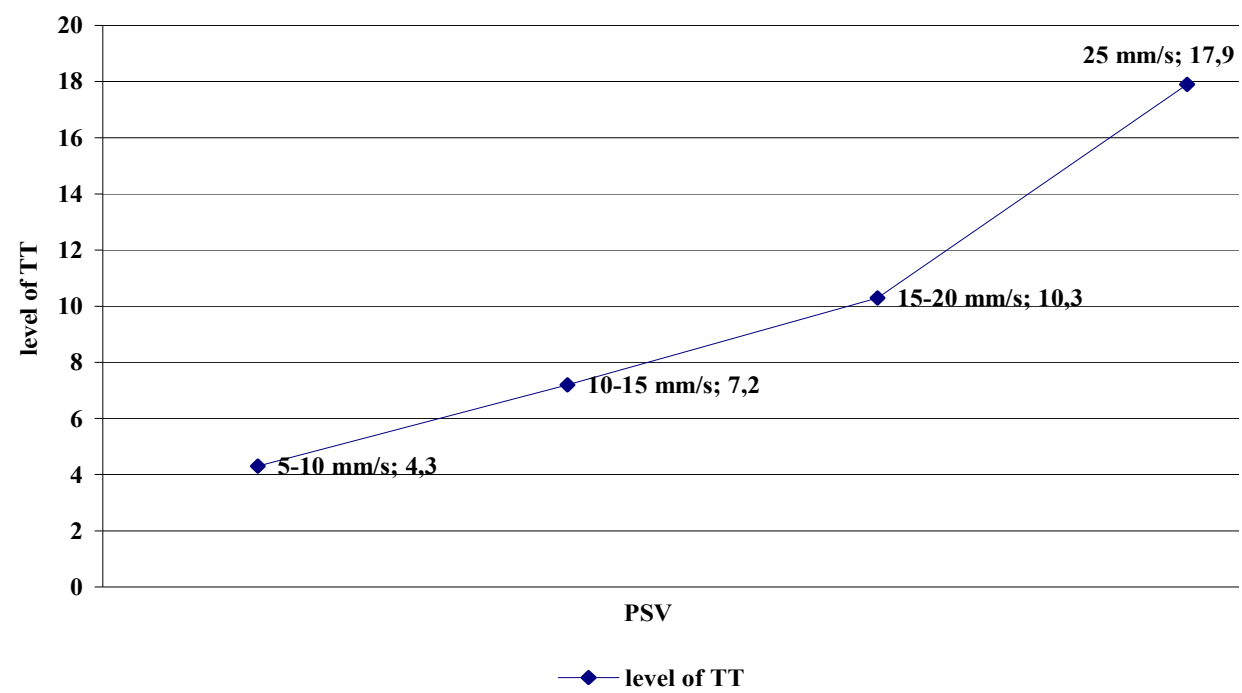

Correlation of the TT and PSV levels in men with arterial hypertension

\section{CONCLUSIONS}

1. Study of penile blood flow in papaverineinduced (at a dose of $2.5 \mathrm{ml}$ ) erection using color Doppler imaging allows us to determine the vascular causes of ED; gives the possibility to differentiate arterial or venous type of disorder.
2. Among the 100 examined men with $\mathrm{AH}$ with sexual dysfunction, arterial type of ED was detected in 72 patients, which confirmed the role of the state of the endothelium of the penis vessels in the mechanism of erection. 
3. One of the reasons for the decrease of TT in patients with $\mathrm{AH}$ may be the deterioration of blood supply to testicular tissue due to angiopathy. Therefore, in the treatment of age-related androgen deficiency in people with $\mathrm{AH}$, the use of medicines that improve microcirculation is indicated.

4. Color Doppler imaging - is a minimally invasive method that allows us to diagnose patients with ED against the background of AH arterial type ED and, thus, to choose the correct, effective therapeutic approach to the treatment of these patients.

5. The study showed a high prevalence of androgen deficiency among middle-aged men with the II degree of $\mathrm{AH}$. In such patients higher blood pressure values were observed compared to those of the same age group, but with a normal level of TT. Decrease of TT level can be considered as one of the factors of the increased arterial stiffness in the presence of AH. Therefore, patients with ED and $\mathrm{AH}$ need careful selection of therapy, taking into account the common pathogenetic links of the disease, for the best treatment outcome.

Conflict of interests. The authors declare no conflict of interest.

\section{REFERENCES}

1. Barrientos $\mathrm{G}$, Llanos $\mathrm{P}$, Basualto-Alarcón $\mathrm{C}$, Estrada M. Androgen-Regulated Cardiac Metabolism in Aging Men. Front Endocrinol. 2020;11:183-86. doi: https://doi.org/10.3389/fendo.2020.00316

2. Hackett G, Kirby M, Wylie K, et al. British Society for Sexual Medicine guidelines on the management of erectile dysfunction in men. 2017. J Sex. Med. 2018;15:43057. doi: https://doi.org/10.1016/j.jsxm.2018.01.023

3. Eriksson J, Haring R, Grarup N, et al. Causal relationship between obesity and serum testosterone status in men: A bi-directional mendelian randomization analysis. PloS One. 2017;12:e0176277:15.

doi: https://doi.org/10.1371/journal.pone.0176277

4. Dominiczak A, Mancia G. Joint editorial for the International Society of Hypertension Guidelines. Hypertension. 2020;75:1334-57.

doi: https://doi.org/10.1161/HYPERTENSIONAHA.120. 15224

5. Elagizi A, Kohler TS, Lavie CJ. Testosterone and cardiovascular health. Mayo Clin Proc. 2018; 93:83-100. doi: https://doi.org/10.1016/j.mayocp.2017.11.006

6. World Health Federation. Elevating Hypertension on the Public Health Agenda. [Internet]. 2018. Available from: http://www.world-heart-federation.org

7. Gorpynchenko II, Hurzhenko YuM, Spiridonenko VV. A study of the effectiveness of the dietary supplement Libedor in men with erectile dysfunction. Men's Health. 2019;1(68):75-8.

doi: https://doi.org/10.30841/2307-5090.1.2019.172855

8. Gorpynchenko II, Romanyuk MG Clinical protocols for providing medical care to patients with erectile dysfunction (project). Men's Health. 2016;3(58):11-22.

9. Klimov AN, Nikulcheva NG. Lipid and lipoprotein metabolism and its disorders. 3th. St. Petersburg: $\mathrm{SPb}$ Piter Com; 1999. p. 512.

10. Kloner RA. Testosterone Replacement Therapy: New Data on Efficacy and Cardiovascular Safety. J of
Card Pharmac and Therape. 2017;22(1):54-55. doi: https://doi.org/10.1177/1074248416646938

11. Kovalenko VM, Dolzhenko MM, Nesukai YeH. Comparative characteristics of the cardiovascular disease prevention in Ukraine and Europe according to EUROASPIRE IV Data: a Hospital Line. Arterial Hypertens. 2016;1.45:29-34.

doi: https://doi.org/10.22141/2224-1485.1.45.2016.74138

12. Luchitskyy VYe. The state of androgen supply and erectile function in men with type 2 diabetes mellitus with obesity. Men's Health. 2018;4(67):76-80. doi: https://doi.org/10.30841/2307-5090.4.2018.171746

13. Luchytskiy VE, Shelkovoy EA, Luchytskiy EV. Penile Doppler sonography in men with erectile dysfunction and type 2 diabetes. Endocrinology. 2016;1(21):45-50.

14. R Core Team. R: A language and environment for statistical computing. $\mathrm{R}$ Foundation for Statistical Computing. Vienna, Austria; 2018. Available from: https://www.R-roject.org/

15. Williams B, Mancia G, Spiering W, Rosei EA, Azizi M, Burnier M, et al. 2018 ESC/ESH Guidelines for the management of arterial hypertension: The Task Force for the management of arterial hypertension of the European Society of Cardiology (ESC) and the European Society of Hypertension (ESH). Europ Heart J. 2018;39(33):3021-104. doi: https://doi.org/10.1093/eurheartj/ehy339

16. Viigimaa M, Vlachopoulos C, Doumas M, Wolf J, Imprialos K, Terentes-Printzios D et al. Update of the position paper on arterial hypertension and erectile dysfunction. J Hypertens. 2020 Jul;38(7):1220-34. doi: https://doi.org/10.1097/HJH.0000000000002382

17. Viigimaa M, Vlachopoulos C, Lazaridis A, Doumas M. Management of erectile dysfunction in hypertension: Tips and tricks. World J of Cardiol. 2014 Sep 26; 6(9):90815. DOI: https://doi.org/10.4330/wjc.v6.i9.908

\section{СПИСОК ЛІТЕРАТУРИ}

1. Barrientos G., Llanos P., Basualto-Alarcón C, Estrada M. Androgen-Regulated Cardiac Metabolism in
Aging Men. Front Endocrinol. 2020. Vol. 11. P. 183-186. DOI: https://doi.org/10.3389/fendo.2020.00316 
2. British Society for Sexual Medicine guidelines on the management of erectile dysfunction in men $-2017 /$ G. Hackett et al. J Sex Med. 2018. Vol. 15. P. 430-457. DOI: https://doi.org/10.1016/j.jsxm.2018.01.023

3. Causal relationship between obesity and serum testosterone status in men: A bi-directional mendelian randomization analysis / J. Eriksson et al. PLoS One. 2017. Vol. 12. P. e0176277.

DOI: https://doi.org/10.1371/journal.pone.0176277

4. Dominiczak A., Mancia G. Joint editorial for the International Society of Hypertension Guidelines. Hypertension. 2020. Vol. 75. P. 1334-1357. DOI: https://doi.org/10.1161/HYPERTENSIONAHA.120.1 5224

5. Elagizi A., Kohler T. S., Lavie C. J. Testosterone and cardiovascular health. Mayo Clin Proc. 2018. Vol. 93. P. 83-100.

DOI: https://doi.org/10.1016/j.mayocp.2017.11.006

6. Elevating Hypertension on the Public Health Agenda / World Health Federation. 2018. URL: http://www.world-heart-federation.org

7. Gorpynchenko I. I., Hurzhenko Yu. M., Spiridonenko V. V. A study of the effectiveness of the dietary supplement Libedor in men with erectile dysfunction. Men's Health. 2019. Vol. 68, No. 1. P. 75-78. DOI: https://doi.org/10.30841/2307-5090.1.2019.172855

8. Gorpynchenko I. I., Romanyuk M. G. Clinical protocols for providing medical care to patients with erectile dysfunction (project). Men's Health. 2016. Vol. 58, No. 3. P. 11-22.

9. Klimov A. N., Nikulcheva N. G. Lipid and lipoprotein metabolism and its disorders. 3th. ed. St. Petersburg: SPb Piter Com, 1999. 512 p.

10. Kloner R. A. Testosterone Replacement Therapy: New Data on Efficacy and Cardiovascular Safety. $J$ of Card Pharmac and Therape. 2017. Vol. 22, No. 1. P. 5455. DOI: https://doi.org/10.1177/1074248416646938
11. Kovalenko V. M., Dolzhenko M. M., Nesukai Ye.H. Comparative characteristics of the cardiovascular disease prevention in Ukraine and Europe according to EUROASPIRE IV Data: a Hospital Line. Arterial Hypertens. 2016. Vol. 45, No. 1. P. 29-34. DOI: https://doi.org/10.22141/2224-1485.1.45.2016.74138

12. Luchitskyy V. Ye. The state of androgen supply and erectile function in men with type 2 diabetes mellitus with obesity. Men's Health. 2018. Vol. 67, No. 4. P. 76-80.

DOI: https://doi.org/10.30841/2307-5090.4.2018.171746

13. Luchytskiy V. E., Shelkovoy E. A., Luchytskiy E. V. Penile Doppler sonography in men with erectile dysfunction and type 2 diabetes. Endocrinology. 2016. Vol. 21, No. 1. P. 45-50.

14. R Core Team. R: A language and environment for statistical computing. $\mathrm{R}$ Foundation for Statistical Computing. Vienna, Austria, 2018.

URL: https://www.R-roject.org/

15. $2018 \mathrm{ESC} / \mathrm{ESH}$ Guidelines for the management of arterial hypertension: The Task Force for the management of arterial hypertension of the European Society of Cardiology (ESC) and the European Society of Hypertension (ESH) / B. Williams et al. Europ Heart J. 2018. Vol. 39, No. 33. P. 3021-3104.

DOI: https://doi.org/10.1093/eurheartj/ehy339

16. Update of the position paper on arterial hypertension and erectile dysfunction / M. Viigimaa et al. J Hypertens. 2020. Jul. (Vol. 38, No. 7). P. 1220-1234. DOI: https://doi.org/10.1097/HJH.0000000000002382

17. Viigimaa M., Vlachopoulos C., Lazaridis A., Doumas M. Management of erectile dysfunction in hypertension: Tips and tricks. World $J$ of Cardiol. 2014. 26 Sep. (Vol. 6, No. 9). P. 908-915.

DOI: https://doi.org/10.4330/wjc.v6.i9.908

The article was received 2020.08.20 